\title{
MEMBUKA JENDELA PANTUN KEHIDUPAN: SEBUAH REFLEKSI IBERAMSYAH BARBARY DALAM BERKARYA
}

\author{
Saefuddin \\ Balai Bahasa Kalimantan Selatan \\ Jalan Jenderal Ahmad Yani Km 32,2, Loktabat, Banjarbaru 70712 Kalimantan Selatan \\ Posel: kangasef@yahoo.co.id
}

\begin{abstract}
Abstrak
Iberamsyah Barbary memiliki kekhasan dalam karyanya. Pantun, sebagai salah satu medium yang ia pilih untuk berkarya, selain ia kemas dengan memberi warna kehidupan sehari-hari, ia juga berikan nuansa keindonesiaan. Ada kegelisahan yang terbaca di dalam pantun-pantunnya. Masalah yang akan dikaji dalam penelitian ini ialah bagaimana wujud refleksi Iberamsyah Barbary dalam menyoroti kehidupanmodern di dalam lingkungannya melalui pantun. Tujuan penelitian ini akan mengungkap wujud refleksi apa saja yang dituangkan Iberamsyah Barbary dalam menyoroti kehidupan modern di dalam lingkungannya melalui pantun. Sebagai seorang sastrawan ia cukup peka dalam menyuguhkan pikirannya melalui karya sastra yang menyoroti kehidupan, melalui pantun-pantun yang bernuansa kehidupan modern, tetapi sarat dengan sampiran dan isi dan pantun tidaklah terkesan menggurui, tetapi mengandung unsur hiburan bagi pembacanya. Metode yang digunakan dalam penelitian ini ialah metode deskriptif-kualitatif. Metode deskriptif ialah suatu metode untuk memperoleh informasi tentang analisis pantun karya Iberamsyah Barbary secara lebih terperinci mealaui analisis sampiran dan isi pantunnya. Hasil penelitian memperoleh gambaran tentang wujud refleksi Iberamsyah Barbary dalam menyoroti kehidupan modern melalui pantun.

Kata kunci: Pantun, refleksi, Iberamsyah Barbary.
\end{abstract}

\section{Opening the Window of Life : A Reflection of Iberamsyah Barbary in His Work}

\begin{abstract}
Iberamsyah Barbary has a peculiarity in his work. He packages it by giving color about daily life and Indonesian taste.There is anxiety that can be seen in his work.The problem which is discussed in this study is how does the reflection form of Iberamsyah Barbary's concern seeing modern life in his environment. This study aims to reveal the kind of reflection form of Iberamsyah Barbary's concern about seeing modern life in his environment. As one of the literary man, he pays attention to presenting his thought through his works, for example, quatrains that have modern life nuance and have lots of massages and the first line of the quatrain. Iberamsyah Barbary's work seems not to lecture someone but it contains entertainment aspects for the readers. This study uses a descriptive qualitative method. It is a method to get information deeply about quatrain analysis by Iberamsyah Barbary through the analysis of first-line quatrain and the content. The result shows the description about the reflection form of Iberamsyah Barbary's concern seeing modern life through quatrain.
\end{abstract}

Keywords: quatrain, reflection, Iberamsyah Barbary.

\section{PENDAHULUAN}

Nusantara dikenal sebagai masyarakat majemuk karena didiami oleh beragam kelompok suku dan budaya yang bermacam-macam. Setiap daerah memiliki adat istiadat dan kebiasaan masing-masing yang tetap mereka jaga dan pertahankan. Mereka menganggap kebiasaan itu sebagai bentuk panduan dalam bertindak dan bertingkah laku dalam komunitasnya. Tindakan dan tingkah laku dalam kelompok masyarakat, perihal mana yang boleh dilakukan dan mana yang tidak boleh dilakukan oleh individu dalam pergaulan sehari-hari dalam bertetangga dan bermasyarakat, telah menjadi kesepakatan bersama yang berwujud kesepakatan yang tidak tertulis (Ali, 1989, hlm. 19). Tidak dapat dipungkiri, pembentukan kesepakatan yang tidak tertulis itu merupakan suatu tatanan yang ada di masyarakat. Selain menjunjung adat istiadat, juga menjunjung 
nilai-nilai yang berlangsung di dalam masyarakat, dalam berbagai sendi kehidupan, baik sebagai individu maupun sebagai kelompok dalam kehidupan masyarakat. Hal tersebut juga berlaku bagi sastrawan yang melihat fenomena kehidupan dan menuangkan fenomena itu ke dalam karya sastra.

Kegelisahan seorang sastrawan yang kemudian dituangkan ke dalam karya sastra merupakan bentuk pengabdiannya pada masyarakatnya. Fenomena-fenomena kehidupan seorang sastrawan yang ada di sekililing kehidupannya menjadi lahan subur untuk dijadikan objek tulisannya.

Salah satu sastrawan lokal yang memiliki kepedulian dalam mengungkapkan kegelisahannya, yaitu Ibramsyah Barbary. Ia salah seorang penulis produktif. Banyak di antara karya-karyanya memuat tentang realitas sosial di lingkungan sekitarnya. Karya sastra Ibramsyah Barbary adalah suatu bentuk kritik pada sebuah realitas sosial, di antaranya ia wujudkan dalam bentuk gurindam dan pantun, di samping karya sastra yang lain berbentuk; puisi, novel, dan cerpen. Karyanya cukup dapat diperhitungkan. Ia memiliki modal ketekunan dalam mengungkap fenomena sosial itu. Penikmat karyanya cukup besar dan setia memberikan apresiasi. Sementara itu, kajian-kajian diskusi atas karyanya memberikan ruang kepada penulis-penulis lain. Dosen, dan mahasiswa juga tak luput dalam memberikan perhatian pada karyanya untuk dijadikan bahan penelitian.

Iberamsyah Barbary tampaknya cukup berbeda dalam mengemas pantunpantun itu, sehingga pantun hasil karangannya dapat memberikan warna tersendiri, tema-tema yang ia buat sangat lengkap. Dari tema ke tema pantun yang ia tulisnya, ia beri ulasan lengkap setiap sampiran dan isinya, selain memberikan nasihat dan sekaligus sebagai bentuk kritik sosial kepada pembacanya, termasuk lingkungan masyarakatnya. Ia juga memberikan nuansa baru yang cukup berbeda. Membaca karyanya, pembaca seolah-olah disuguhkan pada bacaan, seperti sedang membaca karya sastra prosa novel dan cerpen (mengandung alur cerita yang sangat apik). Di dalamnya terdapat tulisan yang bernuansa kehidupan sehari-hari dalam lingkup masyarakat dan tak jarang pula mengungkapkan sebuah kenyataan yang bernuansa keindonesiaan.

Tulisan bernuansa kenyataan kehidupan itu ia tuangkan ke dalam 1000 Guridam dan pantun. Karyanya tersebut sudah diterjemahkan ke dalam bahasa Inggris oleh Balai Bahasa Kalimantan Selatan dengan tujuan untuk memperkenalkan Indonesia melalui karya yang bergenre sastra Melayu. Karya tersebut sarat pesan moral dan nilai-nilai kearifan lokal serta berbagai masalah keindo-nesiaan. Oleh karena itu, 1000 Gurindam bukan hanya tersebar di seluruh Nusantara juga tersebar ke mancanegara, seperti Asia; Singapura, Malaysia, dan Brunei Darrusalam. Karya sastra ini pula tersebar ke belahan Eropa, seperti; Belanda, Jerman, dan Prancis (Barbary, 2019).

Kesadaran seorang penulis dalam sikap hidupnya akan melahirkan suatu sikap yang positif dan harmoni dalam kehidupan bermasyarakat. Sendi-sendi kehidupan yang rukun telah ada sejak lama dalam kehidupan masyarakat di daerah (Abdullah, 2001, hlm. 98). Keharmonisan itu juga tercermin dalam kehidupan sehari-hari masyarakat Banjar, yang terefleksikan dalam sastra lisan, yaitu pantun Banjar. Tidak jarang pula kegelisahan sosial itu muncul ke permukaan. Oleh karena itu, seorang penulislah yang bertugas untuk mengungkap ke dalam sebuah bentuk tulisan, agar persoalan- 
persoalan yang muncul di dalam kehidupan masyarakat dapat teratasi dengan caranya sendiri-sendiri, tentu dengan menggunakan bahasa sastra yang mampu lebih menggugah pembacanya daripada nasihat biasa.

Karya sastra lisan dalam bentuk pantun ialah salah satu bentuk refleksi masyarakat yang mengungkapkan kegelisahannya, misalnya dalam wujud toleransi dan kritik sosial serta masalah kebu-dayaan. Wujud toleransi dan kritik sosial serta masalah kebudayaan itu terung-kapkan dalam pantun Banjar yang kini dapat dikatakan hampir tergilas oleh pesatnya perkembangan teknologi dan kecanggihan zaman. Pantun terasa usang dan jauh dari kehidupan sehari-hari.

Seiring dengan makin pesatnya perkembangan teknologi informasi dan komunikasi, banyak sekali unsur-unsur luar yang masuk memengaruhi kehidupan masyarakat. Unsur-unsur tersebut bertentangan dengan nilai-nilai budaya yang terdapat dalam masyarakat (Lisyawati \& Saefuddin, 2012). Hal ini menyebabkan sering terjadi tindakan dan perbuatan terutama dari golongan muda yang tidak sesuai dengan norma-norma yang berlaku di masyarakat (hlm. 2), seperti terjadinya tawuran antarsiswa, konflik antar desa dan bahkan yang lebih parah lagi terjadinya konflik kekerasan antarkelompok etnik/suku sebagai akibat perbedaan budaya dan ketidak-tahuan dengan budaya setempat (kurang adanya sikap saling menghargai). Hal tersebut juga menimbulkan kerawanan sosial dan perpecahan antarkelompok etnik/suku tersebut (Al-Munawar, 2006, hlm. 37).

Untuk mengantisipasi terjadinya konflik kepentingan dalam suatu masyarakat, perlu adanya proses komunikasi budaya antarsuku dan antaretnik. Proses komunikasi itu dapat pula diwujudkan berupa komunikasi budaya yang berupa tradisi lisan berpantun. Tradisi itu berlangsung biasanya di saat tertentu atau karena keperluan tertentu lainnya yang nuansanya untuk saling menghibur satu sama lain. Selain itu, proses berkomunikasi merupakan suatu keperluan manusia untuk saling mempererat tali silaturahmi dan bukan sekadar karena keperluan, dalam arti untuk semata-mata berkomunikasi, misalnya bertemu dengan orang di suatu tempat atau di jalan (orang yang saling bertemu kemudian hanya saling menyapa). Proses berkomunikasi harus didasarkan pada niat yang tulus serta merupakan perwujudan kesadaran di antara suku-suku, selain karena keperluan dan bahkan manusia baik sebagai individu maupun kelompok masyarakat satu sama lain saling memerlukan (Umar Hasyim, 2009, hlm. 54).

Di sisi lain, kita perlu juga menyadari bahwa proses komunikasi di dalam masyarakat, termasuk dalam kehidupan masyarakat Banjar, untuk menjembatani proses komunikasi yang tidak hanya sekadar berbasa-basi. Masyarakat Banjar merefleksikannya dalam sebuah tradisi berupa sastra lisan, yaitu pantun Banjar. Di dalam pantun Banjar selain proses komunikasi itu terjadi, juga banyak terdapat nilai-nilai toleransi yang diungkapkan oleh penutur Banjar yang maknanya, antara lain sebagai ungkapan untuk saling menghargai, saling menghormati dengan orang yang memiliki pandangan yang berbeda, seperti dalam pengertian toleransi yang telah dipaparkan di atas(Al-Munawar, 2006, hlm. 39).

Penelitian-penelitian mengenai pantun di berbagai daerah telah banyak dilakukan. Penelitian serupa tentang madihin, sastra lisan mirip pantun pernah dilakukan, yaitu di antaranya penelitian tentang fungsi sastra lisan madihin (isinya 
berupa pantun nasihat) dalam masyarakat Banjar oleh Saefuddin dalam Jurnal Telaga Bahasa (Saefuddin, 2016, hlm. 265). Penelitian lain, yaitu Nilai Toleransi dalam Pantun Banjar oleh Saefuddin. Penelitian ini membahas pantun sebagai sarana komunikasi, nilai toleransi pantun yang berkaitan dengan manusia dengan manusia, manusia dengan lingkungan, dan pantun yang berkaitan manusia dengan Sang Pencipta oleh Saefuddin dalam Jurnal Batra (Saefuddin, 2016, hlm. 55).

Oleh karena itulah, tulisan ini membahas bagaimana wujud refleksi Iberamsyah Barbary dalam menyoroti kehidupan modern di dalam lingkungannya. Tujuan penelitian ini mengungkap wujud refleksi apa saja yang dituangkan Iberamsyah Barbary dalam menyoroti kehidupan modern di dalam lingkungannya. Hal itu pula yang membuat penulis tertarik untuk meneliti secara mendalam mengenai isi pantun karya Iberamsyah Barbary dalam mengungkap fenomena sosial ke dalam bentuk pantun Banjar, walaupun dalam pembahasan ini hanya bagian kecil saja dari kumpulan pantun yang berjudul Membuka Jendela Pantun Kehidupan (MJPK).

\section{TEORI}

Pantun merupakan puisi asli Indonesia yang bentuknya terdiri atas empat baris dalam setiap bait, dan bersajak $a b a b$. Baris pertama dan kedua merupakan sampiran sedang-kan baris ketiga dan keempat merupakan isi pantun (Kawi, 1997, hlm. 11). Dalam perkembangan selanjutnya, ternyata bentuk pantun memiliki variasi seperti pantun biasa, pantun kilat, pantun berkait, dan talibun. Bentuk-bentuk tersebut juga terdapat dalam pantun Banjar. Hampir di semua daerah di Indonesia terdapat tradisi berpantun. Pantun tepat untuk suasana tertentu, seperti halnya juga karya seni lainnya hanya tepat untuk untuk suasan tertentu pula. Salah satu tujuan dan fungsi berpantun dalam masyarakat Banjar ialah berpantun dalam prosesi upacara perkawinan pada saat kedua mempelai menerima dan menyambut pasangan pengantin, baik dari pihak laki-laki maupun pihak perempuan untuk menyampaikan sambutan; dengan tujuan berpantun di sini menimbulkan agar menimbulkan suasana keakraban satu sama lain.

Secara struktural fungsi utama pantun dalam ruang lingkup kehidupan masyarakat, yaitu; 1) sebagai media ekspresi estetik, emosional, dan intelektual, 2) sebagai alat penyampai pesan, 3) sebagai wujud identitas kebangsaan, 4) sarana pewarisan nilai-nilai, 5) sebagai wahana pelestarian seni budaya, 6) sebagai alat perekat tali persaudaraan, dan 7) sebagai sarana hiburan (Jamal T Suryanata, 2016). Namun, dari ke tujuh fungsi ini, secara teoretis tampaknya berdiri sendiri-sendiri, pada kenayataanya dalam kehidupan masyarakat sehari-hari ke tujuh fungsi tersebut dapat saja bersifat tumpang tindih atau bahkan mencakup semuanya.Penyajian pantun, baik yang terdokumentasikan maupun yang tidak terdokumentasikan oleh penulisnya, secara umum pantun terikat oleh ketujuh fungsi. Dapat dikatakan seseorang membuat pantun dapat dipastikan dalam dirinya memiliki tujuan, misalnya dalam rangka mengangkat nilai-nilai, mengeratkan tali silaturahmi, dan memberikan hiburan kepada sesama atau pendengarnya. Penulis pantun telah mengekpresikan fungsi-fungsi itu, disadari atau tidak. Seni berpantun pada mulanya hidup dan berkembang dalam tradisi lisan, maka sebagai ikhtiar pewarisannya yang dipandang cukup efektif ialah dengan menggunakan pola, aturan, atau rumusan tertentu. 
Dengan demikian, sebagaimana lazimnya berlaku pada hampir semua bentuk sastra lisan, struktur pantun pun bersifat formualik (A Teuww, 1989, hlm. 7--9). Namun, dibandingkan dengan ragam sastra Melayu lama lainnya (terutama syair, seloka, talibun, dan gurindam), pantun memiliki karakteristik tertentu sebagai ciri pembedanya. Atas dasar itulah sebagian besar pakar sastra mengatakan bahwa pantun merupakan asli Melayu (Indonesia).

Istilah pantun sendiri berasal dari akar kata tun yang berarti mengatur, merangkai, atau menyusun, sedangkan pengertian "pantun" dipandang dengan kiasan(perumpamaan) dan sanjak (puisi), (Hamzah, 2005, hlm.9 dan 28). Namun, kalau kita mengacu pada (Penyusun, 2015, hlm.421), pengertian pantun, yaitu (1) bentuk puisi Indonesia (Melayu), tiap bait (kuplet) biasanya terdiri atas empat baris yang bersajak $(a-b-a-b)$, tiap larik biasanya terdiri atas empat kata, baris pertama dan baris kedua biasanya untuk tumpuan (sampiran) saja dan baris ketiga dan keempat merupakan isi; (2) peribahasa sindiran; (3) jawab (misal pada tuduhan); berkait rangkaian pantun yang sambungmenyambung, misalnya larik kedua dan keempat bait pertama muncul lagi sebagailarik pertama dan ketiga bait berikutnya; pantun rantai. Dalam kaitan ini, pemerian pada bagian (1) tersebut sebenarnya bukan hanya menegaskan pengertian leksi-kalnya, melainkan sudah mencakup serangkaian aturan atau rumusan tertentu sebagai ciri-ciri khas yang melakat pada pantun seperti yang dimaksudkan di atas.

Selanjutnya, sebagaimana dijelaskan dalam Kamus Istilah Sastra pantun dapat dibedakan menjadi dua jenis, ditinjau dari segi hubungan sampiran dan isinya. Pada jenis pertama, sampiran merupakan persiapan fonetis atas isinya dan tidak ada hubungannya antara kedua bagian tersebut. Pada jenis kedua, yang juga disebut "pantun mulia", sampiran tidak hanya mempersiapkan isi secara fonetis, tetapi juga mengisyaratkan isi secara semantis (Abdur Razak Zaidan, 2012, hlm. 27). Dengan demikian, jika kita mengacu pada jenis kedua sebagai kriteria estetisnya, kehadiran dua larik pertama (sampiran) dalam sebuah pantun idealnya bukan sekadar mampu menjalankan fungsinya sebagai acuan fonetis untuk menentukan rima akhir pada dua larik penutupnya, tetapi semestinya sudah menggambarkan pesan (isi) yang ingin disampaikan oleh seseorang pemantun.

Buku Membuka Jendela Pantun kehidupan yang ditulis oleh Iberamsyah Barbary ini sesuangguhnya merupakan rangkaian dari buku kumpulan pantunnyayang telah diterbitkan sebelumnya di bawah tajuk Serumpun Pantu Kehidupan (Jamal T.S., 2016:IX). Isinya kumpulan pantun tersebut mengungkapkan refleksi kegelisahan penulisnya terhadap fenomena kehidupan di sekelilingnya yang memenuhi syarat fungsi-fungsi pantun selain sebagai bentuk kritik sosial penulis terhadap fenomena kehidupan.

Contoh pantun yang telah ada sebelumnya, misalnya ada seorang gadis dan jejaka yang berkenalan, bercinta, atau menyatakan kasihnya.Ungkapan secara langsung dalam pantun diberi antara oleh sampiran sehingga penerima ungkapan itu tidak merasa terkejut. Tanggapan orang yang diajak bicara pun jika bersifat kasar juga tidak begitu menyakitkan hati karena tanggapan itu diperantarai oleh sampiran.

Berikut ini contoh pantun Banjar

iwak sapat jamur sahari 
jangan disangka iwak haruan

kada badapat barang sahari

jangan disangka aku membuang

"ikan sepat jemur sehari

jangan dikira ikan gabus

tidak bertemu satu hari

jangan dikira aku membuang"

nyaman-nyamannya mamakan karak

mamakan karak di papiringan

nyaman-nyamannya balarangan parak

nyaman jua bakurihingan

"enak rasanya makan kerak

makan kerak di piring kecil

enak juga bertunangan

dekat mudah juga bersenyum-senyuman"

buah pisang buah kuini

dijual urang di pasar parit

hati pusang handak babini

tapi aku kada baduit

"buah pisang buah kuini

dijual orang di pasar parit

hati gundak mau beristri

tapi aku tidak berduit"

piungut burung pialing

kandangan tarus ka gambah

taungut bapadah garing

karindangan supan bapadah

"piungut burung pialing

ke Kandangan terus ke Gambah

duduk termenung berkata sakit

tetapi rasa rindu malu mengatakan (Kawi, 2000:10-11).

Dari pantun di atas, dapat kita lihat bahwa penciptaan sampiran tidak berhubungan dengan makna isi. Namun, sampiran itu sering juga mengandung makna. Paling tidak, dua baris yang merupakan sampiran itu ialah kesatuan sintaksis yang memiliki kesatuan makna pula, meskipun maknanya tidak berhubungan dengan makna baris-baris berikutnya. Makna sampiran hanya bersifat permainan; oleh karena bagian ini disebut sampiran. Pantun itu sendiri selesai dalam satu bait.

Jadi, pantun merupakan puisi lama yang berisi pemikiran-pemikiran masyarakat lama yang tidak jarang memuat pandanganpandangan hidup mereka yang mela-hirkan kearifan-kearifan lokal tempat mereka hidup sebagai masyarakat penghasil dari pantun itu sendiri.

\section{METODE}

Pada tahapan pengumpulan data, digunakan metode deskriptif-kualitatif atau studi kepustakaan (library research) dengan teknik pembacaan dan pencatatan. Penerapan metode deskriptif-kualitatif dan teknik ini bertujuan untuk mengumpulkan data pantuan karya Ibramsyah Barbary, yaitu karya sastra yang dijadikan objek penelitian; mengumpulkan ulasan atau pembahasan yang berkaitan dengan objek; dan mengumpulkan penelitian-penelitian yang ada hubungannya dengan penelitian ini.Pada tahapan analisis data digunakan metode deskriptif analitik. Metode ini digunakan dengan cara mendeskrip-sikan data yang kemudian disusul dengan analisis (Ratna, 2013, hlm. 53). (Nazir, 1988, hlm. 65) mengatakan bahwa metode deskriptif analitik bertujuan untuk membuat deskripsi, gambaran atau uraian secara sistematis, faktual dan akurat mengenai fakta-fakta, sifat-sifat, serta hubungan antarfenomena yang diselidiki. Tahapan terakhir dari keseluruhan proses penelitian ialah penyajian analisis data. Hasil analisis data dapat disajikan dalam bentuk jurnal ilmiah.Metode yang digu-nakan pada tahapan ini ialah metode informal atau disebut pula dengan metode penyajian 
secara naratif. Menurut Sudaryanto (Ratna, 2013, hlm.5), metode informal ialah cara penyajian melalui kata-kata biasa.

\section{HASIL DAN PEMBAHASAN}

Pantun-pantun Iberamsyah Bar-bary memuat berbagai tema, tetapi dalam pembahasan ini penulis memilih tema yang mengandung pesan yang ditujukan kepada lingkungan sosial atau lingkungan pembaca yang lebih luas. Isi yang terkandung dalam pantun seperti yang telah dikemukakan dalam pendahuluan, Iberamsyah Barbary membuat pantun dalam bentuk refleksi dan melihat fenomena kehidupan modern dalam ruang lingkup lingkungannya, ia kemas dalam bentuk pantun, sekaligus meng-ajak pembacanya agar memahami bahwa kehidupan tidak berdiri sendiri, tetapi ada orang lain di sekelilingnya. Karena itu, penulis tuangkan pikirannya dalam bait-bait pantun yang nuansanya hiburan, tetapi mengandung pesan-pesan moral. Tema pantun tersebut sebagai berikut.

\section{1) Tema pantun tentang budaya malu}

Benalu tumbuhnya sarat di dahan Patah banyak pohonnya lalu Malu bersuluh sesat di jalan Pepatah bijak ingatlah selalu (Barbary, 2016, hlm. 535)

Kiasan makna ungkapan pantun tersebut, pada sampiran baris pertama begitulah tumbuhnya benalu selalu saja menempel kuat pada dahan. Jika tumbuhan intinya mati, maka mati pula benalunya. Sampiran baris kedua, apabila benalu berbuah lebat bijinya akan menebar pada setiap dahan, tumbuh menghisap pokok pohon, lama-lama mati atau hidup segan mati pun tak mau. Bagian isi baris ketiga, rezeki dan nikmat mustahil didapat tanpa berusaha. Mengharapkan bantuan dan belas kasihan orang lain hanya akan terpenuhi dalam waktu sesaat dan akhirnya nasib diri akan melarat. Isi baris keempat, pepatah bijak banyak mengandung petuah dan hikmah kehidupan, patutlah tuahnya diingat dan diamalkan agar hidup kita mendapat derajatdan muruah berlimpah dalam rido Allah Maha Pemurah.Sampiran dan isi pantun di atas ialah rasa malu ialah nilai sebuah harga diri yang kualitasnya terukur dengan keimanan. Rasa malu merupakn fitrah manusia, amanah terjaga penanda kualitas manusia di hadapan sesama dan Allah Sang Pencipta.

Selain itu, pantun di atas mengandung pesan, bahwa dalam hidup jangan selalu mengeluh dan selalu bergantung kepada orang lain. Hidup jangan sampai diibaratkan dengan pohon benalu (seperti benalu), di mana pun pohon benalu selalu menempel kuat pada pohon yang lain. Jika seseorang sepanjang hidupnya selalu bergantung kepada orang lain, maka ia tidak akan memiliki keman-dirian dan tidak memiliki keberanian untuk mengambil keputusan, karena itu seseorang hendaknya sedini mungkin harus banyak berbekal diri, sehingga kelak di masa tua nanti memiliki bekal atau modal (ilmu pengetahuan) yang cukup agar ia tidak mengalami kesulitan dalam hidup. Ia diibaratkan sudah memiliki suluh sebagai penerang jalan hidup dan tidak akan tersesat di perjalanan. Seseorang jika sudah memiliki kemampuan janganlah lupa pesan bijak untuk tidak melupakan jasa-jasa orang yang telah memberi bekal ilmu pengetahuan kepada dirinya, terutama kepada kedua orang tua yang telah membesarkan dan kepada para guru yang telah membekali ilmu yang telah diterimanya, agar kelak ia menjadi orang yang berguna. Hidup jangan seperti benalu 
selalu bergantung pada pohon lain dan merusak pohon intinya.

Rasa jamu minuman ramuan
Maklum obat sayang di awak
Rasa malu bagian iman
Belum berbuat menimbang banyak
(Barbary, 2016, hlm. 536)

Kiasan makna ungkapan pantun tersebut, pada sampiran baris pertama pagi yang cerah dinanti banyak orang untuk melakukan aktivitas pekerjaan agar lancar apa yang ingin didapat. Sampiran baris kedua, perlombaan manusia dalam memperoleh apa yang diinginkan tersedia sudah, semua nikmat bisa didapat asal bekerja penuh dengan semangat dan berbuat dengan sarat, tetapi berkah bagi umat yang hormat harus dengan syariat (aturan-aturan Allah Swt). Bagian isi baris ketiga, sosok orang perorang yang percaya diri lagimadiri, selalu optimis dalam menghadapi persoalan hidup dan tidak ada rasa putus asa, yang ada ialah bagaimana cara mengatasinya. Isi baris keempat, sosok orang perorang dalam ikhtiar berjuang untuk menempuh dengan segala tenaga yang penuh, kemudian ia berserah diri jiwa raga kepada Allah yang Mahakuasa, ia selalu optimis menunggu rida-Nya, apapun hasilnya, ia akan selalu lapang dada menerimanya. Sampiran dan isi pantun di atas ialah mandiri dalam bersikap, mandiri dalam berkeyakinan, jiwa dan raga tidak akan tergoyahkan, itulah kepribadian yang bermakna lahir batin.

Selain itu, pantun di atas mengandung maksud dalam sampiran bahwa jamu dan kesehatan mengandung korelasi, yaitu jika jamu dikonsumsi untuk kesehatan akan memberi dampak baik bagi kesehatan tubuh. Begitu pula isi dari sampiran pantun berikut, mengandung maksud bahwa pemaknaan malu dalam ajaran Islam bukan saja malu mengandung pengertian tidak berbuat (melakukan suatu tindakan) sesuatu di luar kewajaran dirinya untuk orang lain karena faktor sosial, tetapi malu yang dimaksud oleh penulis pantun secara tidak langsung menyam-paikan pada pembacanya, yaitu malu didasari oleh karena keimanan seseorang. Jika seseorang berbuat sesuatu di luar yang tidak disepakati oleh aturan normanorma yang berlangsung di masyarakat, hendaknya seseorang dalam melakukan tindakan harus mempertimbangkan normanorma yang berlangsung di dalam masyarakatnya sekaligus memperhitung-kan baik buruknya menurut aturan agama yang dianutnya secara lebih berhati-hati.

\author{
Bala lalu musibah bertaut \\ Jumawa melekat celaka datang \\ Bila malu sudah tercabut \\ Jiwa sekarat muka terbuang (Barbary, \\ 2016, hlm. 537)
}

Kiasan makna ungkapan pantun tersebut, pada sampiran baris pertama apabila perilaku manusia sudah membala, maka setelah itu akan berganti dengan musibah-musibah yang akan menimpa pada kehidupan manusia, baik yang berdosa maupun yang tidak, karena keseimbangan alam keseimbangan hidup akan terganggu oleh keserakahan manusia. Sampiran baris kedua, rasa aku diri ialah segala-galanya, maka jumawa diri telah menyatu dalam keangkuhan hidupnya, sosok diri itu telah menggambarkan bara neraka dalam dirinya yang membuat dahaga ketidakpuasan dominan dalam diri dan membuat selalu resah gelisah yang tak berkesudahan. Bagian isi baris ketiga, sosok orang perorang apabila urat malunya sudah tercabut, imannya pun ikut tercabut dalam kehidupannya. Halal dan haram sudah bukan ukurannya dalam masyarakat, ukurannya adalah birahi dan 
nafsu yang tidak berkesudahan. Isi baris keempat, sosok orang yang telah kehilangan rasa malu dalam hidupnya, fitrah jiwanya merana dalam sekarat dan syaraf sensivitasnya pun sudah kebal dengan sentuhan moral, mukanya sudah tidak kenal lagi dengan suasana rasa nurani di sekelilingnya. Sampiran dan isi pantun di atas, rasa malu adalah nilai sebuah harga diri yang kualitasnya terukur denga keimanan. Rasa malu ialah fitrah manusia, amanah yang terjaga, dan sebagai penanda kualitas manusia di hadapan sesama dan di hadapan Allah Swt.

Pantun di atas pula mengandung maksud dalam sampiran bahwa bala selalu beriringan musibah, arti yang dikandung dari sampiran ini jika seseorang dalam hidup selalu berbuat hal yang tidak baik, suatu ketika bala itu akan mendatangkan musiabah di di kemudian hari, bala itu menjadi penyebab terjadinya musibah yang menimpanya. Dalam kehidupan, seseorang atau sekelompok masyarakat kadang-kadang tidak menyadari bahwa sering terjadinya bencana yang menim-panya karena disebabkan oleh perbuat-annya sendiri dengan kata lain, siapa yang menebar ia akan menuai. Pantun pada baris kedua, begitu pula kesembongan seseorang akan mendatangkan celaka yang menimpa pada dirinya, tidak ada satu pun peristiwa di dunia manakala orang sombong atau jumawa itu selalu disenangi oleh orang lain, justru malah sebaliknya kesembongan itu suatu ketika akan membawa malapetaka bagi dirinya.

Kemudian, pada bagian isi bila malu sudah tercabut, jiwa sekarat muka terbuang mengandung maksud apabila pada diri seseorang sudah tidak lagi memiliki rasa malu atau rasa malu dimiliki sudah hilang, seseorang ini akan mengalami musibah atau bencana yang akan menimpa dirinya. Tidak jarang dalam lingkungan di sekitar kita terdapat orang yang memiliki sifat seperti yang dimaksud dalam pantun tersebut. Kadang-kadang sudah berbuat salah, ia tidak merasa salah bahkan merasa benar. Bahkan menunjuk-kan sikap keangkuhan yang luar biasa, semestinya dalam hidup dalam ruang lingkup lingkungan masyarakat, hendak sestiap anggota masyarakat di mana pun ia tinggal (hidup) selalu memperhatikan kaidah-kaidah adat yang berlangsung dalam masyarakatnya, agar kedamaian yang selalu diidam-idamkan oleh setiap orang dapat dicapainya.

\section{Ke depan dituntun tidaklah selalu Teguhkan harap kaki memijak \\ Sopan santun rasalah malu \\ Tumbuhkan sikap sebagai anak (Barbary, 2016, hlm. 538)}

Kiasan makna ungkapan pantun tersebut, pada sampiran baris pertama anak selagi kecil dididik dan dituntun agar mengerti dan mengenal sopan santun adat istiadat cara bermasyarakat. Namun, begitu sudah menginjak dewasa, sudahlah dipercaya dan diharapkan mampu membawa diri sendiri selayaknya, dan dilepas dengan tuntunan doa. Sampiran baris kedua, orang tua sudah yakin melepas anak dan si anak yakin petuah dan nasihat tempat kaki berpijak agar dapat hidup mandiriuntuk membentuk jati dri. Bagian isi baris ketiga, sopan santun adalah bagian dari adab berperilaku, agar di mana kita berada bisa membawa diri, niscaya orang lain akan berkenanmenerima kehadiran kita. Isi baris keempat, anak adalah jiwa yang masih putih bersih atau tabularasa, hendaklah dibekali dengan segan segala bekal pengetahuan dan nasihat-nasihat yang baik, agar ia dapat memilih dan memilah mana pengaruh yang baik dan mana pengaruh yang tidak baik. Sampiran dan isi pantun di atas ialah estafet 
kehidupan manusia adalah dari generasi ke generasi tumbuh kembangnya hendak berlangsung dengan tuntunan dari dalam lingkup keluarga.

Pantun di atas juga mengan-dung maksud bahwa hidup ini ibarat di mana bumi dipijak disitu langit dijunjung di mana orang tinggal dan hidup maka harus menghormati norma-norma kesantunan dan adat istiadat yang dipegang oleh masyarakat setempat. Berpijak pada suatu norma-norma atau ada istiadat tidak bisa selalu mengandalkan apa yang kita miliki, tetapi kita harus menyesuaikan diri dengan lingkungan baru, adat istiadat yang baru, dan kebiasaan yang baru. Sopan santun kepada orang lain dan menunjukkan sikap wajar dengan sendirinya orang lain yang menjadi bagian yang ada dalam lingkungan baru kita, keadaan ituakan memberikan sikap timbal balik kepada kita sebagai orang memperlihatkan sikap sopan santun kepada orang lain. Oleh karena itu, sikap hidup dalam wujud rumah tangga ayah dan ibu hendak menga-jarkan pada anakanak agar dapat memiliki sikap yang dapat membawa diri (sopan santun).

2) Tema pantun tentang budaya antre dan tertib

Santri khatib bicara agama

Ibadah ulama menuntun umat

Antri tertib citra bersama

Indah dirasa santun dilihat (Barbary, 2016. hlm. 549)

Kiasan makna ungkapan pantun tersebut, pada sampiran baris pertama bahwasanya para khatib (pengkhotbah) di mimbar-mimbar mesjid selalu memberi petuah agama pada jamaah majelis saat salat Jumat berlangsung. Selain itu, para santri di pondok-pondok pesantren selalulah belajar tentang agama. Kedua, ulama ialah penuntun umat juga tempat bertanya tentang segala persoalan kehidupan beragama dalam amal ibadah yang nyata di dunia untuk mengantarkan seseorang ke akhirat kelak. Ketiga, di dalam suatu kelompok masyarakat bila membudayakan antre dan tertib, maka akan terlihat rasa kemanusiaan yang hakiki dan berbudaya, serta bermartabat karena di dalamnya tampak adanya saling menghargai satu sama lain, dan akan terlihat pemandangan yang amat elok dipandang mata serta dapat kita rasakan suatu kedamaian dalam hidup. Keempat, suatu yang tertata rapi tentulah akan memberikan kesan nuansa keindahan, cita rasa pemandangan atau suatu wujud keindahan yang disenangi oleh semua orang. Semua orang mengerti dan menye-nangi keindahan, tetapi tidak banyak orang yang mengerti untuk mewujudkan keindahan itu untuk urusan kepentingan bersama. Keindahan itu semestinya tumbuh dari kesadaran bersama pula.

Selain itu, pantun di atas juga menyiratkan dan mengandung maksud bahwa dalam hidup ini kadang-kadang pesan kebaikan itu hanyalah ungkapan yang terus menerus dikumandangkan oleh setiap orang, tetapi sulit untuk dilaksa-nakan. Bahkan tidak jarang pula orang yang mengerti tentang aturan norma agama, tetapi tidak menjalankan aturan norma itu. Hal ini dapat menyebabkan sulit tumbuhnya kesadaran dalam melakukan suatu yang menjadi tuntunan atau anjuran agama, karena kadang-kadang seseorang akan mencontoh orang yang dapat dijadikan anutannya. Tidak jarang pula muncul pernyataandari seseorang, bahwa siapa cepat siapa dapat walaupun dia datang terlambat. Contoh itu dapat kita lihat dalam budaya antre di masyarakat dan kebiasaan ini menghambat untuk tumbuhnya kesadaran budaya antre.

Kita menyadari dan bahkan mengetahui bahwa budaya antre itu ialah 
budaya yang baik untuk dilaksanakan, karena satu sama lain tidak memiliki kesadaran untuk memulainya, maka kebiasaan itu sulit untuk dapat diwujudkan dalam kehidupan nyata di kehidupan seharihari. Oleh karena itu, pantun di atas menyampaikan pesan sekaligus bentuk kritik, jika budaya antre itu dilaksanakan sebagai kebiasaan sehari-hari, maka lambat laun budaya antre ini akan tercipta dan tumbuh di dalam masyarakat, seiring dengan kebiasaan itu ada dan dijadikan budaya sehari-hari dalam rutinitas kesehari-harian. Boleh jadi, budaya antre ini harus dimulai dari masing-masing individu, keluarga, dan masyarakat dan jika kesadaran itu tumbuh dan dimulai maka kebiasaan tidak dapat lagi dirasakan sebagai sesutu yang sulit untuk dilaksanakan.

\section{Menebar menanami kena mentari Layak diyakini dalam berharap Sabar memahami makna antri Sebaik insan dalam bersikap (Barbary, 2016, hlm. 550).}

Kiasan makna ungkapan pantun tersebut, pada sampiran baris pertama bahwasanya menanam sesu-atu tanaman hendaklah cukup terkena sinar matahari, sebagai unsur kehidupannya agara tumbuh sempurna. Kedua, bahawsanya meyakini sesuatu untuk berharap, di balik itu haruslah berbuat dengan pengetahuan yang telah dimiliki agar harapan terwujud menjadi kenyataan sesuai dengan keyakinan diri. Ketiga, bahwasanya antre bukan sekedar mematuhi peraturan, tetapi harus memahami mengapa antre itu harus dilakukan. Keempat, bahwasanya mema-tuhi setiap aturandalam kegiatan ber-masyarakat dan bernegara, bukan saja karena aturan yang mengikat, tetapi karena harus tumbuhnya kesadaran diri untuk memahaminya, itulah sebaik sikap dalam hidup.Budaya antri merupakan cirri karakter bangsa dapat dilihat dari sifat ratarata masyarakat berperilaku dalam bersikap kesehari-harian, termasuk masalah disiplin dan budaya antre, semua dapat terbentuk oleh pendidikan dan kesadaran diri.

Selain itu, pantun di atas juga menyiratkan maksud bahwa dalam hidup ini kadang-kadang pesan mengajak orang lain untuk berbuat baik tumbuhan itu hanya dibiarkan tumbuh sendri tanpa di rawat dengan baik. Begitu pula menebar kebaikan tidak hanya sekali dan terus berharap orang lain mengikuti untuk berbuat hal yang sama. Oleh karena itu, memberikan contoh harus dengan berbuat secara terus menerus dan dibarengi dengan sikap sabar, sehingga hasil yang akan dicapai di kemudian harinya pun akan dapat memuaskan semua pihak. Barulah akan dirasakan betapa bermanfaatnya bahwa budaya antri itu, bukan saja bagian yang harus diwujudkan dalam kehidupan sehari-hari, tetapi sebuah bentuk keharusan setiap individu sebagai makhluk sosial, agar citra diri manusia tercermin dalam kehidupan nyata.

\section{PENUTUP}

Pantun dalam kumpulan Membuka Jendela Pantun Kehidupan merupakan refleksi seorang penyairnya (Iberamsyah Barbary) menyoroti kehidupan di sekelilingnya dan pada umumnya kehidupan di Kalimantan Selatan. yang sudah tidak asing lagi dengan budaya berpantun. Oleh karena itu, penyair sangatlah mudah menyampaikan pesan-pesan melalui pantun, khususnya pantun-pantun yang berkeanaan dengan kehidupan sehari-hari di lingkungan penyairnya. Dari lima puluh tema tentang liku-liku kehidupan penyairnya, kemudian ia kemas ke dalam sebuah pantun-pantun yang 
bernuansa kehidupan, penulis memilih tematema di antaranya tema yang berkaitan dengan tema budaya malu dan budaya antre. Tema budaya malu dan budaya antre dalam kumpulan pantun tersebut memuat enam bait pantun yang memuat tema budaya malu dan budaya antre, mengapa penulis memilih tema ini, karena; 1) tema ini menarik untuk dibahas, 2) tema ini melekat dengan kehidupan sehari-hari di masyarakat, baik masyarakat yang berada di Banjarbaru maupun masyarakat yang umumnya di Kalimanta Selatan, 3) tema ini sangat mencolok di antara tema-tema lainnya.

Kedua tema tersebut, dapat disimpulkan bahwa pantun tema budaya malu, tema pantun ini memuatkan bait yang berkaitan dengan budaya malu yang oleh penulisnya budaya malu ialah diibaratkanmanusia yang tidak memiliki rasa malu di dalam kehidupan masya-rakatnya, ia seperti pohon benalu. Pohon benalu itu selalu menempel di pohon apa saja dan biasanya pohon benalu kalau menempel di pohon lainnya akan merusak pohon intinya, mulai batang, ranting, dan daunnya. Begitu pula manusia yang tidak memiliki rasa malu, biasanya ia selalu merusak, membuat onar di sekiling atau dengan orang yang ia ikutinya. Ciri-ciri orang yang tidak memiliki rasa malu, ialah orang yang bermuka dua atau dalam bahasa agama disebut sebagai orang munafik atau ibarat ke mana angina bertiup ke sana ia mengikutinya atau memiliki pendirian yang tetap.

Kemudian, pantun yang bertema budaya antre merupakan tema yang melekat dengan kehidupan nyata di masyarakat. Di dalam suatu kelompok masyarakat, budaya antre dan tertibmenjadi sebuah harapan penyair yang dapat berwujud sebagai aktivitas kehidupan sehari-hari, seperti yang telah diajarkan norma agama. Jika budaya antre dan tertib itu dapat dijalankan oleh masyarakat di dalam setiap kesempatan, maka akan terlihatrasa kemanusiaan yang hakiki dan berbudaya serta bermartabat, karena di dalam kenyataan itu akan tampak adanya saling menghargai satu sama lain, dan akan terlihat pemandangan yang menampakan nilai-nilai yang dapat kita rasakan suatu kedamaian dalam hidup. Selain itu ,tampak terlihat suatu yang tertata rapi tentulah akan memberikan kesan nuansa yang positif, cita rasa pemandangan sebagai wujud keindahan yang disenangi oleh semua orang. Semua orang mengerti dan menyenangi kein-dahan, tetapi tidak banyak orang yang mengerti untuk mewujudkan keindahan itu untuk kepentingan bersama. Oleh karena itulah, untuk mewujudkan keindahan itu semestinya tumbuh dari kesadaran bersa-ma pula.

\section{DAFTAR PUSTAKA}

A Teuww. (1989). Teori sastra. Jakarta: Balai Pustaka.

Abdullah, M. (2001). Pluralisme agama dan kerukunan dalam keagamaan. Jakarta: Penerbit Buku.

Abdur Razak Zaidan, A. K. R. H. (2012). Kamus istilah sastra. Jakarta: Balai Pustaka.

Al-Munawar, S. A. H. (2006). Fikih hubungan antar agama. Jakarta: Penerbit Ciputat Press.

Ali, H. M. D. (1989). Islam untuk disiplin ilmu hukum sosial dan politik. Jakarta: Bulan Bintang.

Barbary, H. I. (2016). Membuka jendela pantun kehidupan. Banjarmasin: Pustakan Banua.

Hamzah, A. (2005). Sastra melayu lama dan raja-rajanya. Jakarta: Dian Rakyat.

Jamal T Suryanata. (2016). Syariah kitab pantun mengurai makna menuai hikmah (prolog) dalam membuka jendela pantun kehidupan. Banjarmasin: Pustaka Banua.

Kawi, D. (1997). Pantun Banjar. Banjarmasin: Bagian Proyek 
Pembinaan Bahasa dan Sastra Indonesia dan Daerah Kalimantan Selatan.

Lisyawati, \& Saefuddin. (2012). Tatakrama adat istiadat masyarakat Banjar. Pontianak: Stain Press.

Nazir. (1988). Metode penelitian. Jakarta: Ghalia.

Penyusun, T. (2015). Kamus Besar Bahasa Indonesia. Jakarta: Balai Pustaka.

Ratna, N. K. (2013). Teori, metode, dan teknik penelitian sastra. Yogyakarta: Pustaka Pelajar.

Umar Hasyim. (2009). Toleransi dan kemerdekaan beragama dalam Islam sebagai dasar. Jakarta: Pustaka Baru.

A Teuww. (1989). Teori sastra. Jakarta: Balai Pustaka.

Abdullah, M. (2001). Pluralisme agama dan kerukunan dalam keagamaan. Jakarta: Penerbit Buku.

Abdur Razak Zaidan, A. K. R. H. (2012). Kamus istilah sastra. Jakarta: Balai Pustaka.

Al-Munawar, S. A. H. (2006). Fikih hubungan antar agama. Jakarta: Penerbit Ciputat Press.

Ali, H. M. D. (1989). Islam untuk disiplin ilmu hukum sosial dan politik. Jakarta: Bulan Bintang.

Barbary, H. I. (2016). Membuka jendela pantun kehidupan. Banjarmasin: Pustakan Banua.

Hamzah, A. (2005). Sastra melayu lama dan raja-rajanya. Jakarta: Dian Rakyat.

Jamal T Suryanata. (2016). Syariah kitab pantun mengurai makna menuai hikmah (prolog) dalam membuka jendela pantun kehidupan. Banjarmasin: Pustaka Banua.

Kawi, D. (1997). Pantun Banjar. Banjarmasin: Bagian Proyek Pembinaan Bahasa dan Sastra Indonesia dan Daerah Kalimantan Selatan.

Lisyawati, \& Saefuddin. (2012). Tatakrama adat istiadat masyarakat Banjar. Pontianak: Stain Press.

Nazir. (1988). Metode penelitian. Jakarta: Ghalia.

Penyusun, T. (2015). Kamus Besar Bahasa Indonesia. Jakarta: Balai Pustaka.

Ratna, N. K. (2013). Teori, Metode, dan Teknik penelitian sastra. Yogyakarta: Pustaka Pelajar.

Saefuddin.(2016).Fungsi sastra lisan madihin dalam masyarakat Banjar. JurnalTelaga Bahasa, volume 4, nomor 2, hlm.265--280. Gorontalo: Balai Bahasa Gorontalo.

Saefuddin.(2016). Nilai toleransi dalam pantun Banjar. Jurnal Batra volume 2, nomor 1, hlm 55. Bengkulu: Kantor Bahasa Bengkulu.

Umar Hasyim. (2009). Toleransi dan kemerdekaan beragama dalam Islam sebagai dasar. Jakarta: Pustaka Baru. 
Telaga Bahasa Vol.8, No.2, Oktober 2020 